\title{
The Aporia of EU Citizenship
}

\author{
Serhii Lashyn ${ }^{1}$ D
}

Accepted: 7 April 2021 / Published online: 16 April 2021

(c) The Author(s) 2021

\begin{abstract}
EU citizenship finds itself in but a deadlock. Certainly no longer being just a symbol of European integration but still far away from a meaningful status of its holders, Union citizenship fails to find its place in the legal landscape of the EU. Having sketched out the current state of EU citizenship and some of its outstanding problems, this article suggests to analyse Union citizenship anew and free from the constraints of legal methodology. In order to do that, this piece employs the works of Jacques Derrida and, on the background of his views on Europe, deconstructs EU citizenship unravelling its aporia.
\end{abstract}

Keywords EU $\cdot$ Citizenship $\cdot$ Europe $\cdot$ Derrida $\cdot$ Deconstruction

\section{Introduction}

EU citizenship is an outstanding and yet one of the most obscure concepts of EU law. Being 'an expression of the legal core of the EU' (Shaw 2003, p. 310), it is still hardly noticeable in the legal landscape of the EU. Union citizenship has attracted vast attention in the scholarship but is nonetheless treated just as 'one of the European Union's most symbolic endeavours' (Sarmiento and Sharpston 2017, p. 226). Definitely, EU citizenship now lives ‘a life of its own' (Besson and Utzinger 2008, p. 186). But what is that life?

Seen solely through the lens of EU law, it appears that Union citizenship has fallen victim to the teleological approach to interpreting EU law which is criticised for explicating it the way it has to be rather than the way it actually is (Somek 2017, pp. 64-67). Being called citizenship and honoured as something that is 'destined to be the fundamental status of nationals of the Member States,' (Grzelczyk, para.

I thank the anonymous reviewer whose great suggestions and thoughtful comments have helped me to improve this article significantly. Any mistakes shall be attributed to me only.

Serhii Lashyn

serhii.lashyn@outlook.com

1 Doctoral student at Universität Hamburg, Hamburg, Germany 
31) it has been teleologically reduced to a 'sub-set of national citizenship' (Hansen 1998, p. 761). Put simplistically, everyone sees in EU citizenship what they want to see. As demonstrated below on the examples of the most aching shortcomings of Union citizenship, attempting to understand it relying solely on the means of legal research is a dead frost. Interpreting EU citizenship in the context leads to diverging conclusions and bias. Instead, Union citizenship shall be interpreted within itself, free from 'outside-text' (Derrida 1998, p. 158). That is why this contribution suggests employing Jacques Derrida's oeuvre and deconstructing EU citizenship.

The article sets the scene with a short description of EU citizenship and some of its outstanding issues. Then, the piece makes a short investigation into how the notion of citizenship changes in the global world of today. After that, the article proceeds to its main part, namely deconstruction of EU citizenship. Having presented an overview of Jacques Derrida's views on Europe, the piece deconstructs EU citizenship from within and demonstrates what is the true cause of EU citizenship's failures. A short conclusion comes at the end.

\section{EU Citizenship and its Issues}

\section{The Past and Present of EU Citizenship}

The most widely accepted timeline of EU citizenship divides its history before and after the Maastricht Treaty. However, the true watershed is actually the Treaty of Paris that came much earlier into being. Back then in 1951, shortly after the Schuman Declaration, the six founding nations undertook 'to remove any restriction' (Article 69(1) of the Treaty of Paris) for the professionals in the coal and mining industry. Exactly this was the true birth of Union citizenship as we know it today, admittedly in a limited form but with all the essential features already present (Maas 2014 , p. 800), such as freedom of movement and non-discrimination. As to the time before the Treaty of Paris, this period is sparsely studied in the literature. It suffices to note that the foundations of Union citizenship were perhaps laid down as early as in the times of the Roman Empire (Marks 2012, pp. 7-9) and developed through the following centuries of shared culture and lasting connections (Beetz et al. 2017, pp. 437-438).

After the Treaty of Paris, the formation of Union citizenship speeded up. Serious discussions in various forms (Blanchet 2016, pp. 145-147) on introducing something that would be actually called citizenship began in the 1970s (Van Eijken 2015, p. 12) and intensified in the 1980s (Hansen 1998, p. 752). Those discussions culminated in the formal birth of EU citizenship proper with the adoption of the Maastricht Treaty. EU citizenship was a significant event as it was conceived as one of the core elements of the rapidly evolving EU's legal edifice (Oosterom-Staples 2018, p. 438) and back then 'raised many hopes' (Besson and Utzinger 2008, p. 185). The introduction of EU citizenship fitted into the more general processes of constitutionalising the Union and ultimately was one of the things that signalled the slow development of the EU towards a federation of European nations (Van Eijken 2015, pp. 27-28). 
Turning now to the contemporary legal framework, EU citizenship relies on both fundamental Treaties of the EU: TEU and TFEU. Also, European citizens' rights are fixed in the Charter of Fundamental Rights and detailed in the Citizenship Directive. The Court of Justice has been playing a landmark role in the development and further sophistication of Union citizenship (Besson and Utzinger 2008, pp. 191-192; Kochenov 2009, pp. 209-211). This article avoids giving a whole and voluminous overview of the most notable decisions of the Court of Justice in the realm of EU citizenship as there is an extensive scholarship that does this job thoroughly and excellently (Davies 2018, pp. 1449-1457; Lenaerts 2015, pp. 2-8, 2013, pp. 570-582; De Waele 2010, pp. 323-328).

In order to acquire EU citizenship, one shall get a Member State's passport, as '[e]very national of a Member State shall be a citizen of the Union' (Article 9 TEU). This 'derivative' (Mindus 2017, p. 15; Besson and Utzinger 2008, p. 190) nature of EU citizenship was coined by Dimitry Kochenov as the ius tractum principle (Kochenov 2009 p. 181). Union citizenship gives its holders a number of rights (Article 39-46 of the Charter of Fundamental Rights of the European Union) associated therewith, namely the freedom of movement and residence (Articles 20(2)(a), 21 TEU), political rights, consular assistance and diplomatic protection (Articles 20(2)(c), 23 TEU), the right to petition EU institutions (Articles 20(2)(d), 24, 227 TEU), the right to access to the documents (Article 15(3) TFEU), and the right to non-discrimination (Citizenship Directive, Article 24, Recital 20). Arguably, the list of rights remains open (Mindus 2017, p. 11; Kochenov 2009, p. 193). As to the duties, although the Treaties specifically state that '[c]itizens of the Union shall ... be subject to the duties provided for in the Treaties,' (Article 20(2) TFEU) none knows what those duties are and indeed such duties 'only exist as one word' (Kochenov 2014, p. 483). Whether this is good or bad is naturally subject to debate (Oosterom-Staples 2018, p. 437; Bellamy 2015, pp. 560-565) and remains 'wholly obscure' (Shaw 2003, p. 298). Overall, the limited scope of the rights attached to EU citizenship, especially when compared to the state of affairs before Union citizenship was introduced, their even more limited applicability, and the de facto submission of Union citizenship to the Member States' nationality let Dora Kostakopoulou describe EU citizenship as 'actually nothing more than a pale shadow of its national counterpart' (Kostakopoulou 2007, p. 625).

The role that Union citizenship now plays in the sophisticated mechanics of European integration is not easily comprehensible. At least in the times of its creation, EU citizenship was constructed 'with the individual, the citizen, in mind' (Kochenov 2013, p. 202). The whole endeavour was about empowering Europeans, on the one hand, and bringing Europe closer to them, on the other. However, EU citizenship seems to have not added much to the right to free movement and non-discrimination that were in operation long before the introduction of Union citizenship (Van den Brink 2018, pp. 2-3). This is the primary reason for the recurring sense of disappointment found in the scholarship and the failure to draw a distinction between EU citizenship and 'market citizenship' (Van Eijken 2015, pp. 15-17). 


\section{Citizenship without Community}

This part deals with the issues surrounding Union citizenship that can be collectively described as the lack of content. Specifically, this contribution investigates the exclusion, social deficiency of EU citizenship, and how it has changed the scope of EU law at large. Expressed in the terms of the Derridean discourse, EU citizenship is now citizenship without community, ${ }^{1}$ and below is demonstrated why.

\section{Exclusion}

The relationship between the Member States and the Union in the realm of citizenship is rather 'uneasy' (Oosterom-Staples 2018, p. 431). Since the very introduction of EU citizenship, it has been sharply criticised for the exclusion of third-country nationals who are resident in the EU (Naujoks 2020, pp. 13-14; Hansen 1998, pp. 753-754). Further, the problem of exclusion especially hurts minorities, such as those EU citizens who are perceived as Roma and expelled on the grounds of their (assumed) ethnicity. ${ }^{2}$ Member States have been excluding some groups of their own population from full national citizenship and thus EU citizenship, as it was the case with the United Kingdom (Oosterom-Staples 2018, pp. 440-441) and Latvia (Kochenov and Dimitrovs, 2016, pp. 63-74) or, by contrast, opened the nationality gates wide to everyone who can afford it, as it was the case with Cyprus and Malta (Joppke 2018, pp. 865-868; Džankić 2018, pp. 10-11). Due to the link between EU citizenship and Member States' nationalities, the tensions between member countries and the Union regarding the personal scope of EU citizenship arise on the regular basis.

Surely, for the proper functioning of a polity, 'the principle of democratic inclusion' (Besson and Utzinger, 2008, p. 188) is indispensable. A suggested response to the problem of exclusion that is widespread in the literature is conditioning EU citizenship upon residence in the EU (Oosterom-Staples 2018, p. 458; Bauböck 2015, p. 73; Besson and Utzinger 2008, p. 190; Hansen 1998, pp. 754-755; Bhabha 1998, p. 605). The obvious shortcoming of this issue is that it contradicts the provisions of the Treaties that subject EU citizenship to Member States' nationality, not residence. On the other hand, when considered in the broader terms of the functionality of citizenship, exclusion is an inevitable and even necessary component of this concept (Shaw 2003, p. 295). For the functioning of any community, it is necessary to draw a line between insiders and outsiders, between 'us' and 'them.' As aptly put by Jacqueline Bhabha, EU citizenship 'establishes a unitary basis for exclusion rather than a coherent set of criteria for inclusion' (Bhabha 1998, p. 604).

\footnotetext{
${ }^{1}$ John D. Caputo referred to the views of Derrida on community, the exclusion inherent thereto and the European project in general as a 'community without community' (Derrida, 1997, p. 122).

${ }^{2}$ For example, the expulsions of Roma in summer 2010 in France (Parker, 2012, pp. 477-481).
} 


\section{Reluctant Social Solidarity}

In line with the pattern studied by T. H. Marshall (1950), EU citizenship contains not only civil and political elements but also a social one. Specifically, when EU citizens move to another Member State, they 'enjoy equal treatment with the nationals of that Member State' (Citizenship Directive, Art. 24(1)) in terms of social solidarity. But in reality, the 'social dimension' (Shaw 2003, p. 301) of EU citizenship is substantially hindered by the legislative exceptions, the Court's case law and Member States' reluctance to embrace the social facet of Union citizenship.

First, for the first three months of their residence in another Member State, EU citizens are not entitled to social assistance at all (Citizenship Directive, Art. 24(2)). Furthermore, only those EU citizens who are economically active or have sufficient financial resources are entitled to reside in another Member State for more than three months (Citizenship Directive, Art. 7(1)). Moreover, even in the period of residence after initial three months, EU citizens are not entitled to maintenance aid for studies and student loans unless they are employed or their family member is employed (Citizenship Directive, Art. 24(2)). Finally, in this period, EU citizens are entitled to social assistance only as long as they do not become a 'burden' on the social system of the host Member State (Citizenship Directive, Recital 16, Art. 7(b)). The wording of the Directive makes it clear that mere recourse to social assistance shall not be regarded as an indication of becoming a social burden and grounds for expulsion. However, the jurisprudence of the Court of Justice has turned the situation upside down. The post-Brey case law largely responded to the growing concern among the richer Member States about welfare tourism (Barbulescu and Favell 2020). Particularly, the Court interpreted the Citizenship Directive in a way that establishes 'the link ... between the requirement to have sufficient resources as a condition for residence and the concern not to create a burden on the social assistance systems of the Member States' (Dano, para. 77) as the basis for the right to residence in another Member State. As greatly described by Mantu and Minderhoud (2017, p. 712), the case law created a true Catch-22 situation: residing over three months, an EU citizen may apply for social assistance but the fact of application will most likely be treated as a sign of becoming a burden which, in its turn, leads to the termination of the right to residence.

These developments of EU law correspond to the change of public perception of EU citizens from 'free movers' to 'EU immigrants' (Barbulescu and Favell 2020, pp. 154-155). In fact, EU citizenship was conceived with market logic in mind. When it moved closer to the citizens and evolved in the direction of crossborder social solidarity, it stumbled upon the apparent reluctance of the Member States. However, a truly social EU citizenship is drastically needed for the cohesion and legitimisation of the European project (Bruzelius et al. 2017, pp. 11-12). On a broader scale, these developments echo the centuries-long 'tension between man the citizen and economic man' (Ignatieff 1987, p. 400) that began when the market-centred theory clashed with the republican understanding of citizenship. 


\section{In Search of (Lost) Purely Internal Situations}

Reverse discrimination, meaning a grotesque situation when Member States treat EU citizens from fellow Member States better than their own citizens due to the operation of EU law (Shuibhne 2002, p. 740), was prophesied at the very dawn of the European project (Mindus 2017, p. 9) and now is one of the most hotly discussed (Iglesias Sánchez 2018, pp. 8-9) issues of EU law. The origin of the problem is the scope of European law that does not cover what is called purely internal situations (Kochenov 2009, pp. 212-213). However, EU citizenship has turned the situation upside down (Kochenov 2011, p. 67). As Henri de Waele notes, 'an EU citizenship placed on an equal footing to national citizenship spells a quick death to the concept of reverse discrimination' (De Waele 2010, p. 329). Now, if any right of a European citizen is violated, EU law can intervene into something that would have been undoubtedly classified as an internal matter in the pre-Maastricht era (Kochenov 2011, pp. 56-58). How EU citizenship has impacted the application of EU law may be vividly illustrated by the case of D'Hoop.

A Belgian national went for her secondary education in France but then got back to Belgium to get her university degree (D'Hoop, paras 8-9). When she applied for a social benefit aimed at helping fresh graduates, she was denied due to the provision in the law that set forth secondary education in Belgium as a condition for the benefit (D'Hoop, paras 10-11). The whole case was a matter between a Belgian national residing in Belgium against the Belgian state. And yet, the Court applied EU law and the provisions on EU citizenship. The reasoning encompasses the fact that the appellant had used her right to the freedom of movement and thus is entitled to the protection against her own Member State's measures that can impose some negative effects on the previous exercise of that right (D'Hoop, para. 29). Based on that and intending to shield the appellant against discrimination, the Court forces a Member State to treat its own national as its own national (D'Hoop, para. 30). The Court expressly acknowledges that it is examining a law that discriminates not between home citizens and citizens from other Member States but between Belgian citizens and Belgian citizens (D'Hoop, para. 33).

Although the matter was between a Member State and its own national and there were no cross-border elements, the Court took EU citizenship of the appellant as enough ground to intervene in the sovereign matters of state regulation and told a Member State how to treat its own nationals. How come EU law went that far? It seems that there are now no internal situations at all, as far as a Union citizen is affected. Fortunately, it is a straight pathway to eradicating reverse discrimination but a rhetoric question then arises: do we want to achieve that by means of such a broad expansion of the scope of EU law?

\section{The Changing Paradigm of Citizenship}

Discussing EU citizenship is not complete without paying close attention to the changing nature of citizenship in the modern world and how EU citizenship fits the existing or emerging standards of citizenship. When looking for some kind of legal 
standard of citizenship, one is usually referred to the much-criticised (Macklin 2017, pp. 493-494; Kunz 1960, pp. 537-539) Nottebohm case that is called by some an 'international norm' (Joppke 2018, p. 870) in the realm of citizenship. Applying the Nottebohm matrix to EU citizenship on the example of the Micheletti case, commentators suggest that EU citizenship notably departs from the established Nottebohm standard (Mindus 2017, p. 14; Kochenov 2007, pp. 128-129). However, such a conclusion is simply wrong. What Micheletti actually says is that one Member State, as a part of the Union, cannot doubt the possession of the Union citizenship granted to an individual by another Member State. Micheletti does not say that third countries cannot challenge the possession of EU citizenship. Such a challenge can be based on the Nottebohm 'genuine link' requirement. Therefore, saying that Nottebohm and Micheletti are incompatible is simply not true.

Turning now to the sociological and philosophical standards, one can find Aristotle's definition of citizenship of use. However, this definition is flagrantly outdated. In the globalised world of today, application of the standards stemming from ancient Greece is indeed destined to no avail (Ignatieff 1987, p. 401). Another standard, much fresher and often cited, even 'almost canonical' (Shaw 2003, p. 297), is the one developed by T. H. Marshall. This one suggests viewing citizenship in three constituent components: civil, political, and social (Marshall 1950, p. 10). More importantly, however, Marshall also presents three factors that enabled the development of citizenship as we know it today: a more equal income distribution, common culture and experience, enrichment and universalisation of citizenship status (Marshall 1950, p. 75). When seen through the lens of Marshall's works, EU citizenship, as demonstrated in the section on its history, certainly builds upon shared cultural heritage. Further, Union citizenship enriches the status of its holders allowing them to integrate themselves into a larger cosmopolitan community. Moreover, the development of EU citizenship rights follows the same pattern as national citizenship: first, the civil element, then the political one, and social rights coming last (Marshall 1950, pp. 27-28). What Union citizenship still lacks is, however, true social solidarity and more political empowerment.

However instructive the writings of Marshall may be, the notion of citizenship is not what it was in the previous century. The paradigm of citizenship changes and already looks much different. In this regard, one shall recall what Yasemin Soysal notes about 'reconfiguration of citizenship from a more particularistic one based on nationhood to a more universalistic one based on personhood' (Soysal 1994, p. 137). Caused by various factors, citizenship is steadily experiencing the process of denationalisation (Bosniak 2000, pp. 453-454). A more proactive outlook of people who do not simply participate but also take the responsibility and courage to impact their polity pushes the current development of citizenship in the direction of globalisation (Gaffney 2016, pp. 14-16). The latter, taken together with the growing need to counter nationalist sentiments, shapes yet unknown and undiscovered form of citizenship (Rubenstein and Adler 2000, pp. 543-548).

It is difficult to assess how much this new and revisited form of citizenship is applicable to EU citizenship. Probably the most accurate description remains the one formulated by Linda Bosniak quite a while ago: 'while Union citizenship represents a real departure from the national model, the departure is limited in both 
kind and effect' (Bosniak 2000, p. 459). Still, however limited this departure is, EU citizenship is nonetheless notable in its novelty and partition with the nation-constrained model.

\section{Deconstructing EU Citizenship}

This section forms the core of the argument as it deconstructs EU citizenship. Before doing that, a run-through of Jacques Derrida's views on the world after the Cold War and the European project is presented in order to frame the deconstruction of EU citizenship into the broader context of Derrida's thinking.

\section{Jacques Derrida, the New International and Europe}

The challenges facing the world after the collapse of the Soviet Union and end of the Cold War were apparent and alarming to Derrida. In his Specters of Marx, Derrida resolutely rejects Fukuyama's premature declaration of the end of history (Derrida 1994). For Derrida, the world faces new challenges and continues to be haunted by the past. Among many other things, Derrida critically engages with international law and international institutions. Acknowledging that some progress was made, Derrida points to two major shortcomings of the international law system: first, its conceptual dependence on the European philosophy and culture and, second, the adjacent domination of the powerful Western states in the practice of international law (Derrida 1994, p. 104). Derrida calls for and simultaneously projects a major transformation of international law. Comparing its development to the development of human rights over the course of centuries, Derrida believes that international law should become more inclusive and embrace diverse social, cultural and economic backgrounds (Derrida 1994, p. 105). Calling his views 'anti-statist,' Derrida further notes that 'the super-State, which might be an international institution, may always be able to limit the appropriations and the violence of certain private socio-economic forces' (Derrida 1994, p. 105). When perceived in the context of the European integration, one may suggest that EU may be so far the pioneer of what Derrida calls 'the New International': a transnational institution that is unprecedented and unique in its diversity and inclusiveness.

Jacques Derrida paid much more attention to the then emerging European project in his essay titled The Other Heading, although a considerable portion thereof is devoted to reflections on Paul Valéry. From the very outset, Derrida is ostensibly biased against national identity, in the name of which, in Derrida's opinion, 'the worst violences' (Derrida 1992, p. 6) are done. Consequently, he is doubtful as to whether the European integration shall build upon the past with all its ups and downs or rather depart from it in pursuit of creating a truly new and ultimately better Europe (Derrida 1992, p. 8). Apparently, Derrida would have preferred the latter option, as, in his opinion, '[o]ld Europe seems to have exhausted all the possibilities of discourse and counter-discourse about its own identification' (Derrida 1992, p. 26). 
The main part of Derrida's argument is set around community and difference. The notion of community is significantly troubled in the eyes of Derrida. He points to the unavoidable exclusion that any polity-building and community-making are accompanied with. John D. Caputo elaborates on this writing that "the very notion is built around a defense that a "we" throws up against the "other," that is, it is built around an idea of inhospitability, an idea of hostility' (Derrida 1997, p. 113). In a deconstructive manner, Derrida undermines the idea of building a viable and lively European community as any such community will be based on excluding those who do not belong thereto. And as noted above, EU citizenship has proved to be the vehicle of such exclusion.

Derrida articulates the main contention of the European project as following: '[n] either monopoly nor dispersion, therefore. This is, of course, an aporia, and we must not hide it from ourselves' (Derrida 1992, p. 41). The aporia identified by Derrida is the necessity of preserving state sovereignty and cultural difference of the Member States, on the one hand, and the need to build an ever closer union and a common identity, on the other hand. Although Derrida, of course, does not propose any solution, his thinking tends towards 'self-difference, difference to itself, that which differs and diverges from itself, of itself' (Derrida 1992, p. 10). This proposal is, however, cannot be simplified to the degree of the EU motto 'United in Diversity' and Derrida further elaborates two options: 'cultivating the difference-to-oneself (with oneself) that constitutes identity or by confining oneself to an identity wherein this difference remains gathered' (Derrida 1992, p. 11). As such, European identity can emerge as something completely different from itself and from the identities of the Member States or as simply a collection of the national identities with all the tensions among them. The shortcoming of the first option is a threat of totalitarian regime that makes the European project yet another European empire; the latter option promises a loose union and weak Europe. Expectedly, this aporia cannot be resolved with a simple answer if aporia is something that can be resolved at all.

Moving to the next part, it shall be noted that the 'ambiguity in the ideal of European identity' (Parker 2012, p. 485) is ostensibly one of the sources of the ambiguity of EU citizenship. It is hardly surprising, as Union citizenship was in part introduced as a means of creating a European identity (Mindus 2017, p. 8). Quite a while ago, Derrida sharply criticised the results of the European integration writing that Europe did not attain 'the perfection of the universal State or of liberal democracy' and did not 'even come close' (Derrida 1994, p. 79). Derrida calls for '[a] Europe that sets the example of what a politics ... and an ethics could be, ... which would be capable of non-binary judgments' (Derrida 2006, p. 410). Ultimately, the European project so far has not reinvented itself and continues to exist in its defining constraints. Brexit and the EU-wide rise of populism show that there is too much Europe and, at the same time, there is too little of Europe.

\section{Deconstruction of Union Citizenship}

It should be noted right from the start, that deconstruction is not a method and it is not going to be applied as a method here. In fact, deconstruction critically engages 
with any methodology (Zima, 2002, p. 29). Most probably, nobody, including Derrida, knows what deconstruction really is. Deconstruction is something that happens inside the text. That is why it would be more correctly to say that this article itself does not deconstruct EU citizenship but rather reveals and observes the deconstructive forces that swirl and boil inside Union citizenship. This piece undertakes 'to question in a radical way the dominance of concepts as well as systematic terminology' (Zima 2002, p. 1) that dominate the scholarly discourse on EU citizenship. Deconstruction is 'a transformative experience that makes us escape from a regime of thinking' (Lawlor 2015, pp. 124-125) which is precisely what is needed to study EU citizenship that has been so far researched with a great deal of bias or pre-established assumptions.

EU citizenship seeks its own place in the framework of the European integration and within the coordinates of citizenship and belonging. On the one hand, EU citizenship concedes and downgrades itself: it 'shall be additional to and not replace national citizenship' (Article 9 TEU). The Treaties make it clear that EU citizenship is not equal to national citizenship, it is not and will not be the same and it is something inferior to Member States' nationalities. On the other hand, EU citizenship is still called a citizenship and forms the fundamental status of its holders. EU law establishes an unequivocal and direct link (Worster 2018, p. 359; Bhabha 1998, p. 603 ) between the Union and its citizens, be it in the matters of representation, rights or non-discrimination etc.

This means that EU citizenship is nothing but an aporia. Aporia is a Greek word that may be roughly translated as 'impasse.' Derrida specifically draws a distinction between aporia and problem. For Derrida, aporia is a 'nonpassage' that is paralysing and, at the same time, fascinating as it shields the way to a place where 'there is no longer any problem' and where the problem simply cannot happen (Derrida 1993, p. 12). Aporia is also not an exquisite synonym for paradox (Derrida 1997, p. 32). As such, an aporia is characterised by a hidden and fierce opposition that is placed at its very core. EU citizenship does not simply have such an opposition inside but even more-EU citizenship is formed by this opposition and such an opposition makes EU citizenship what it truly is. Resolving this aporia requires a whole new and radically distinct approach as an 'aporia is reflected or capitalized in abyss and requires more than ever thinking differently' (Derrida 1992, p. 46).

Embarking now on the deconstruction of EU citizenship, the opposition between national citizenship and belonging to an international community shall be first critically assessed and mercilessly challenged. As many aporias, EU citizenship finds itself on the borderline of two extremes: it stays somewhere between the national and supranational. Located between these two poles, EU citizenship cannot be identified with either. On the one hand, it stays really close to national citizenship: it is derived therefrom and dependent on it. On the other hand, it is nevertheless citizenship of the Union and asserts itself only when its holder crosses the inner borders of the EU. Still, however supranational EU citizenship is, the Union is constrained to Europe or rather a select few of European countries - hence one can hardly talk about EU citizenship as a form of belonging to a truly global community. It is clear that EU citizenship is in the twilights and builds upon two opposite concepts. EU citizenship is precisely what Derrida calls undecidable. 
The first stage of deconstruction consists of attacking the established oppositions that are, in Leonard Lawlor's words, 'violent hierarchies' of two terms (Lawlor 2015, p. 123). Deconstruction reverses such oppositions and reveals that the dominating term, in fact, 'presupposes traits found in the subordinate term' (Lawlor 2015, p. 123). The opposition identified above is obviously one of dominance and submission. National citizenship is presupposed and assumed as something ultimately better and superior to the vague supranational forms of belonging. This is evident, for example, when one sees how EU citizenship is tied to Member State's nationality: the latter holds the former hostage as the withdrawal of Member State's nationality immediately terminates EU citizenship. Here deconstruction comes into play and unravels this aporia as 'deconstruction always criticizes instituted structures' (Lawlor 2015, p. 130). This structure of submitting an international form of belonging to the one of a nation-state is grounded on the supreme power of Member States and their self-perception as 'masters of the Treaties' (Alter 1998). However, the superior term in this opposition is somewhat dependent on the subordinate term-one shall recall the words of the Court of Justice on EU citizenship: it is 'destined to be the fundamental status of nationals of the Member States' (Grzelczyk, para. 31). The national status of Member States' citizens includes this valuable supranational status and thus EU citizenship really adds value to Member States' nationalities but it does not work the other way around: the national status does not enrich EU citizenship.

Here, one shall not yield to the temptation of oversimplification. Putting the suppressed supranational form of belonging in the dominating position and subordinating the national form thereto in the spirit of globalisation and cosmopolitanism would be a great mistake. Neither EU citizenship lets decipher itself that easily nor deconstruction can be carried out in such a mechanical and straightforward way. As John D. Caputo succinctly describes deconstruction's attentiveness, '[a] deconstructor is like an inspector who is gravely concerned with a little crack he observes in an airplane's fuselage ... while everyone else on the inspection team is eager to break for lunch' (Derrida 1997, p. 79). Deconstruction does not put hierarchies upside down but looks at the cause of hierarchies and ultimately destroys them.

So how have we come to this hierarchical opposition wired inside EU citizenship? This is where deconstruction carries on to the second stage. In this phase, deconstruction identifies what made the opposition possible (Lawlor 2015, p. 124). Deconstruction looks closely at how the object of its attention produces the hierarchical opposition without being confined to either of the terms in that opposition (Lawlor 2015, p. 124). Ultimately, deconstruction leads to eliminating the hierarchy and creating an ultimately new concept that could not exist in the environment of the opposition that was attacked (Lawlor 2015, p. 124).

To look for answers, one shall investigate and dissect the meaning of EU citizenship. Employing Derrida's thinking, EU citizenship differentiates itself from other meanings and contains some traces of those meanings. Although 'radicalized to the point of unintelligibility' (Gutting 2015, p. 83) as nearly everything with the philosophy of Derrida, the notion of trace can be described as meanings that are inherent to a signifier and by means of differentiation make that signifier distinctive. However, '[a] trace is, of course, not a presence' (Gutting 2015, p. 82) but rather, as the name suggests, only a trace of the presence of other meanings. 
In the case of EU citizenship, two traces can be easily found.

The first one is the trace of Member States' nationality. As noted above, Member States' nationality is a prerequisite to EU citizenship. Without Member States' nationality, EU citizenship loses its meaning and cannot be acquired. Member States' nationality defines the scope of EU citizenship; even more, as the Member States act as gatekeepers by means of shaping their legislation on national citizenship, this meaning of Member States' nationality overtakes control and effectively commands the meaning of EU citizenship where only its trace is present.

The second trace, hidden better but definitely having no less importance, is the trace of citizenship. Not the Member States' nationality, of course, but citizenship as such. First and foremost, the Treaties manifestly and unequivocally provide that EU citizenship cannot replace Member States' nationality which means that Union citizenship is not a citizenship. Further, the Treaties do not provide EU citizenship's duties, as well as any hints to the procedure of losing Union citizenship. Put shortly, the Treaties reinforce the assertion that EU citizenship is not and cannot be citizenship thus making the concept dependent on the meaning of citizenship as such. When a concept is built so heavily on negating another concept and differentiating itself therefrom, the concept becomes heavily dependent on the concept it negates. At this point, one can formulate an aporetic but very honest description of EU citizenship: a citizenship that is not a citizenship but is a citizenship.

The above exploration of the traces present in the meaning of EU citizenship explains, construes and constructs the deconstructive opposition identified earlier. EU citizenship was conceived and formulated based on the distinction of Union citizenship from Member States' nationality and citizenship as such. Very importantly for the discussion, the latter two match and do not differentiate. Member States' nationality is a citizenship. Thus, Union citizenship builds upon differentiating itself from two ultimately equal meanings. This is exactly the 'hyper- (or infra-) ontological force that disrupts what would otherwise be a perfect fit between signs' (Gutting 2015 , p. 78) that returns us to the biased and fierce opposition between citizenship and non-citizenship found in the first place.

As ' $\mathrm{t}$ ] he movements of deconstruction do not destroy structures from the outside' (Derrida 1998, p. 24), the deconstruction revealed above was demonstrated based solely on the text. The case law of the Court of Justice, let alone the scholarship, is the context and cannot really clarify the meaning of EU citizenship or substantially change it. So, what is one left with at this point? It seems like ruins and, partially, it is the case. However, deconstruction is not destruction but 'a transgression of boundaries, a revelation of contradictions, and a dissection' (Zima 2002, p. 24). What deconstruction does is that it 'overturns a hierarchy in the metaphysical oppositions in order to displace the system as a whole' (Stocker 2006, p. 189). The piece at hand indeed does not aim at destroying EU citizenship. Deconstruction leads to constructing again, de-constructing in a new and distinctive way. As such, '[d]econstruction is a way of giving things a new twist; it is bent on giving things a new bent, which is what sets the nerves of both essentialists and conventionalists on edge' (Derrida 1997, p. 42).

Therefore, EU citizenship shall be reinvented, even if this is impossible. Deconstruction is 'a certain experience and experiment of the possibility of the impossible: 
the testing of the aporia from which one may invent the only possible invention, the impossible invention' (Derrida 1992, p. 41). What would be such an impossible invention of Union citizenship?

EU citizenship shall become different to itself and within itself. In order to prove and validate itself, EU citizenship shall be freed from the shackles of the opposition it builds upon and get reimagined beyond Member States' nationality and supranational form of belonging. Union citizenship has to relieve itself from the weight of the accepted categories, given assumptions, and widely spread biases. The EU as such has partially achieved that: it does no longer try to put itself into someone other's boxes. Deconstruction does not put a thing in a new and better suited box; it destroys the boxes. For such an unusual and hardly definable entity as the EU, its constituent component shall be equally special and unique. Criticising the established system of international law and functioning of international institutions, Derrida aptly notes that there will be an emergence of 'something which would go beyond ... beyond citizenship, beyond belonging to a state, to a given nation state' (Derrida 1997, p. 12). This will be not a reinvention of the nation-state and belonging thereto but 'a new concept of citizenship, of hospitality, a new concept of the state, of democracy' (Derrida 1997, p. 12). EU citizenship is destined to become such a new concept.

EU citizenship shall not and cannot be simply fixed, complemented, supplemented or strengthened. Instead, Union citizenship has to 'attain, by deconstruction, its ultimate foundation' (Derrida 1998, p. 60). Of course, the emergence of such a new EU citizenship is difficult to achieve and this is not going to happen in the short term. Member States will stay reluctant to yield the power over their subjects but this is not the problem; the problem is that Member States perceive any true reimagination of EU citizenship as a loss of power. A reinvented EU citizenship 'does not fit the established codes and therefore a decision about it seems to be impossible. It is the experience of what, although foreign to the calculable and the rules, is still obligated' (Lawlor 2015, p. 125). However impossible, such a decisive and unprecedented move is urgently needed for the European project and its prime beneficiaries-the citizens.

\section{Conclusion}

As demonstrated above, EU citizenship is heavily troubled. Some rights but no duties. Introduced to eliminate discrimination, it has failed to do so. Meant to unite, Union citizenship operates by means of exclusion and division. The social dimension is still lagging far behind. With all these, EU citizenship has nevertheless managed to cause what seems to be an irreversible shift in the application of EU law. Defining and delimiting EU citizenship is a task that not easier than tackling the enumerated issues. None precisely knows what it is and, more importantly, what it should be. The aporia of EU citizenship can be unbiasedly and substantively studied only from the standpoint of Derrida's works.

The deconstruction of EU citizenship 'reveals certain highly specific anomalies or conflicts of overt and covert sense brought ... by various attempts by 
commentators of a more orthodox persuasion to bring that text into line with their own fixed ideas of interpretative fidelity and truth' (Norris 2015, p. 37). This piece has discovered the central deconstructive force of Union citizenship: the opposition between national citizenship and the supranational form of belonging. This deconstructive movement has been caused by construing EU citizenship with the traces of the meaning of Member States' nationality and citizenship as such. As the two match, the deconstructive contention at the core of Union citizenship was unavoidable from the start.

EU citizenship shall be redone. This is by all means not an easy task as it requires completely new and different thinking about citizenship and European identity. As much as Europe shall 'become more than a market or a single currency, more than a neo-nationalist conglomerate, more than a new armed force' (Derrida 2006, p. 410), a reinvented EU citizenship shall go 'beyond nationality and national citizenship to something post-national, post-geographic' (Derrida 1997, p. 119). Union citizenship shall go beyond established categories or rather establish a category of its own making. In the words of Derrida, EU citizenship shall make 'possible the very thing that it makes impossible' (Derrida 1998, p. 143).

Funding Open Access funding enabled and organized by Projekt DEAL. no funding.

\section{Declarations}

Conflict of interest There are no conflicts of interest.

Open Access This article is licensed under a Creative Commons Attribution 4.0 International License, which permits use, sharing, adaptation, distribution and reproduction in any medium or format, as long as you give appropriate credit to the original author(s) and the source, provide a link to the Creative Commons licence, and indicate if changes were made. The images or other third party material in this article are included in the article's Creative Commons licence, unless indicated otherwise in a credit line to the material. If material is not included in the article's Creative Commons licence and your intended use is not permitted by statutory regulation or exceeds the permitted use, you will need to obtain permission directly from the copyright holder. To view a copy of this licence, visit http://creativecommons.org/licen ses/by/4.0/.

\section{References}

Alter, K.J. 1998. Who Are the "Masters of the Treaty"? European Governments and the European Court of Justice. International Organization 52 (1): 121-147. https://doi.org/10.1162/002081898550572.

Barbulescu, R., and A. Favell. 2020. Commentary: A Citizenship without Social Rights? EU Freedom of Movement and Changing Access to Welfare Rights. International Migration 58 (1): 151-165. https://doi.org/10.1111/imig.12607.

Bauböck, R. 2015. The Three Levels of Citizenship in the European Union. Phenomenology and Mind 8: 66-76.

Beetz, J.P., L. Corrias, and B. Crum. 2017. We the People(s) of Europe: Polity-Making and Democracy in the EU. European Law Journal 23 (6): 432-440. https://doi.org/10.1111/eulj.12269.

Bellamy, R. 2015. A Duty-Free Europe? What's Wrong with Kochenov's Account of EU Citizenship Rights: A Duty-Free Europe? European Law Journal 21 (4): 558-565. https://doi.org/10.1111/eulj. 12142 . 
Besson, S., and A. Utzinger. 2008. Toward European Citizenship. Journal of Social Philosophy 39 (2): 185-208. https://doi.org/10.1111/j.1467-9833.2008.00421.x.

Bhabha, J. 1998. 'Get Back to Where You Once Belonged': Identity, Citizenship, and Exclusion in Europe. Human Rights Quarterly 20 (3): 592-627. https://doi.org/10.1353/hrq.1998.0023.

Blanchet, T. 2016. From Workers to Citizens: The Evolution of European Citizenship. New Journal of European Criminal Law 7 (2): 142-150. https://doi.org/10.1177/203228441600700204.

Bosniak, L. 2000. Citizenship Denationalized. Indiana Journal of Global Legal Studies 7 (2): $447-$ 509. https://doi.org/10.2139/ssrn.232082.

Bruzelius, C., C. Reinprecht, and M. Seeleib-Kaiser. 2017. Stratified Social Rights Limiting EU Citizenship: Stratified Social Rights-EU Citizenship. JCMS: Journal of Common Market Studies 55 (6): $1-15$.

Davies, G. 2018. Has the Court Changed, or Have the Cases? The Deservingness of Litigants as an Element in Court of Justice Citizenship Adjudication. Journal of European Public Policy 25 (10): 1442-1460. https://doi.org/10.1080/13501763.2018.1488881.

De Waele, H. 2010. EU Citizenship: Revisiting its Meaning, Place and Potential. European Journal of Migration and Law 12 (3): 319-336. https://doi.org/10.1163/157181610X520391.

Derrida, J. (1992). The Other Heading: Reflections on Today's Europe (P. A. Brault \& M. B. Naas, Trans.). Indiana University Press.

Derrida, J. (1993). Aporias (T. Dutoit, Trans.). Stanford University Press.

Derrida, J. (1994). Specters of Marx: The State of the Debt, The Work of Mourning and the New International (P. Kamuf, Trans.). Routledge.

Derrida, J. (1997). Deconstruction in a Nutshell: A Conversation With Jacques Derrida (J. D. Caputo, Ed.). Fordham University Press.

Derrida, J. (1998). Of Grammatology (G. C. Spivak, Trans.). Johns Hopkins University Press.

Derrida, J. (2006). A Europe of Hope (P. DeArmitt, J. Malle, \& K. Saghafi, Trans.). Epoché: A Journal for the History of Philosophy, 10(2), 407-412 https://doi.org/10.5840/epoche20061028

Džankić, J. 2018. Immigrant Investor Programmes in the European Union (EU). Journal of Contemporary European Studies 26 (1): 64-80. https://doi.org/10.1080/14782804.2018.1427559.

Gaffney, J. 2016. Another Origin of Totalitarianism: Arendt on the Loneliness of Liberal Citizens. Journal of the British Society for Phenomenology 47 (1): 1-17. https://doi.org/10.1080/00071 773.2015.1097405.

Gutting, G. 2015. The Obscurity of "Différance." In A Companion to Derrida, ed. Z. Direk and L. Lawlor, 72-88. New Jersy: Wiley.

Hansen, R. 1998. A European Citizenship or a Europe of Citizens? Third Country Nationals in the EU. Journal of Ethnic and Migration Studies 24 (4): 751-768. https://doi.org/10.1080/13691 83X.1998.9976664.

Iglesias Sánchez, S. 2018. Purely Internal Situations and the Limits of EU Law: A Consolidated Case Law or a Notion to be Abandoned? European Constitutional Law Review 14 (1): 7-36. https:// doi.org/10.1017/S1574019618000111.

Ignatieff, M. 1987. The Myth of Citizenship. Queen's Law Journal 12: 399-420.

Joppke, C. 2018. The Instrumental Turn of Citizenship. Journal of Ethnic and Migration Studies 45 (6): 858-878. https://doi.org/10.1080/1369183X.2018.1440484.

Kochenov, D. 2007. EU Influence on the Citizenship Policies of the Candidate Countries: The Case of the Roma Exclusion in the Czech Republic. Journal of Contemporary European Research 3 (2): $124-140$.

Kochenov, D. 2009. Ius Tractum of Many Faces: European Citizenship and the Difficult Relationship between Status and Rights. Columbia Journal of European Law 15 (2): 169-237.

Kochenov, D. 2011. A Real European Citizenship: A New Jurisdiction Test: A Novel Chapter in the Development of the Union in Europe. Columbia Journal of European Law 18: 55-109.

Kochenov, D. 2013. The Citizenship Paradigm. Cambridge Yearbook of European Legal Studies 15: 197-225. https://doi.org/10.5235/152888713809813648.

Kochenov, D. 2014. EU Citizenship without Duties. European Law Journal 20 (4): 482-498. https:// doi.org/10.1111/eulj.12095.

Kochenov, D., and A. Dimitrovs. 2016. EU Citizenship for Latvian "Non-Citizens": A Concrete Proposal. Houston Journal of International Law 38 (1): 55-97.

Kostakopoulou, D. 2007. European Union Citizenship: Writing the Future. European Law Journal 13 (5): 623-646. https://doi.org/10.1111/j.1468-0386.2007.00387.x. 
Kunz, J.L. 1960. The Nottebohm Judgment. American Journal of International Law 54 (3): 536-571. https://doi.org/10.2307/2195307.

Lawlor, L. 2015. Deconstruction. In A Companion to Derrida, ed. Z. Direk and L. Lawlor, 122-131. New Jersy: Wiley.

Lenaerts, K. 2013. The Concept of EU Citizenship in the Case Law of the European Court of Justice. ERA Forum 13 (4): 569-583. https://doi.org/10.1007/s12027-013-0279-y.

Lenaerts, K. 2015. EU Citizenship and the European Court of Justice's 'Stone-by-Stone' Approach. International Comparative Jurisprudence 1 (1): 1-10. https://doi.org/10.1016/j.icj.2015.10.005.

Maas, W. 2014. The Origins, Evolution, and Political Objectives of EU Citizenship. German Law Journal 15 (5): 797-819. https://doi.org/10.1017/S2071832200019155.

Macklin, A. 2017. Is It Time to Retire Nottebohm? AJIL Unbound 111: 492-497. https://doi.org/10. 1017/aju.2018.5.

Mantu, S., and P. Minderhoud. 2017. EU Citizenship and Social Solidarity. Maastricht Journal of European and Comparative Law 24 (5): 703-720. https://doi.org/10.1177/1023263X17741271.

Marks, G. 2012. Europe and Its Empires: From Rome to the European Union. JCMS: Journal of Common Market Studies 50 (1): 1-20. https://doi.org/10.1111/j.1468-5965.2011.02218.x.

Marshall, T.H. 1950. Citizenship and Social Class. Cambridge University Press.

Mindus, P. 2017. European Citizenship after Brexit: Freedom of Movement and Rights of Residence. Palgrave Macmillan. https://doi.org/10.1007/978-3-319-51774-2.

Naujoks, D. 2020. Atypical Citizenship Regimes: Comparing Legal and Political Conceptualizations. Comparative Migration Studies 8 (1): 1. https://doi.org/10.1186/s40878-019-0156-0.

Norris, C. 2015. Truth in Derrida. In A Companion to Derrida, ed. Z. Direk and L. Lawlor, 21-41. New Jersy: Wiley.

Oosterom-Staples, H. 2018. The Triangular Relationship Between Nationality, EU Citizenship and Migration in EU Law: A Tale of Competing Competences. Netherlands International Law Review 65 (3): 431-461. https://doi.org/10.1007/s40802-018-0122-9.

Parker, O. 2012. Roma and the Politics of EU Citizenship in France: Everyday Security and Resistance. JCMS: Journal of Common Market Studies 50 (3): 475-491. https://doi.org/10.1111/j. 1468-5965.2011.02238.x.

Rubenstein, K., and D. Adler. 2000. International Citizenship: The Future of Nationality in a Globalized World. Indiana Journal of Global Legal Studies 7 (2): 519-548.

Sarmiento, D., and E. Sharpston. 2017. European Citizenship and Its New Union: Time to Move On? In EU Citizenship and Federalism, ed. D. Kochenov, 226-242. Cambridge: Cambridge University Press.

Shaw, J. 2003. The Interpretation of European Union Citizenship. The Modern Law Review 61 (3): 293-317. https://doi.org/10.1111/1468-2230.00145.

Shuibhne, N.N. 2002. Free Movement of Persons and the Wholly Internal Rule: Time to Move On? Common Market Law Review 39 (4): 731-771.

Somek, A. 2017. Is Legality a Principle of EU Law? In General Principles of Law: European and Comparative Perspectives, ed. S. Vogenauer and S. Weatherill, 53-75. Hart Publishing.

Soysal, Y. N. (1994). Limits of Citizenship: Migrants and Postnational Membership in Europe. University of Chicago.

Stocker, B. 2006. Routledge Philosophy Guidebook to Derrida on Deconstruction. Routledge.

Van den Brink, M. 2018. EU Citizenship and (Fundamental) Rights: Empirical, Normative, and Conceptual Problems. European Law Journal 25 (1): 1-16. https://doi.org/10.1111/eulj.12300.

Van Eijken, H. (2015). EU Citizenship \& the Constitutionalisation of the European Union. Europa Law Publishing.

Worster, W.T. 2018. Brexit and the International Law Prohibitions on the Loss of EU Citizenship. International Organizations Law Review 15 (2): 341-363. https://doi.org/10.1163/1572374701502005.

Zima, P.V. 2002. Deconstruction and Critical Theory. Continuum. 


\section{Cases Cited}

Elisabeta Dano and Florin Dano v Jobcenter Leipzig [2014] Case C-333/13 ECLI:EU:C:2014:2358, 2014 Digital Reports of Cases

Marie-Nathalie D'Hoop v Office national de l'emploi [2002] Case C-224/98 ECLI:EU:C:2002:432, 2002 European Court Reports 6191

Rudy Grzelczyk v Centre public d'aide sociale d'Ottignies-Louvain-la-Neuve [2001] Case C-184/99 ECLI:EU:C:2001:458, 2001 European Court Reports 6193

Publisher's Note Springer Nature remains neutral with regard to jurisdictional claims in published maps and institutional affiliations. 